\title{
Front Matter: Volume 6694
}

, "Front Matter: Volume 6694," Proc. SPIE 6694, Instruments, Methods, and Missions for Astrobiology X, 669401 (26 October 2007); doi:

10.1117/12.775479

SPIE Event: Optical Engineering + Applications, 2007, San Diego, California, United SPIE. States 


\section{PROCEEDINGS OF SPIE}

\section{Instruments, Methods, and Missions for Astrobiology $X$}

Richard B. Hoover

Gilbert V. Levin

Alexei Y. Rozanov

Paul C. W. Davies

Editors

28-30 August 2007

San Diego, California, USA

Sponsored and Published by

SPIE

Volume 6694 
The papers included in this volume were part of the technical conference cited on the cover and title page. Papers were selected and subject to review by the editors and conference program committee. Some conference presentations may not be available for publication. The papers published in these proceedings reflect the work and thoughts of the authors and are published herein as submitted. The publisher is not responsible for the validity of the information or for any outcomes resulting from reliance thereon.

Please use the following format to cite material from this book:

Author(s), "Title of Paper," in Instruments, Methods, and Missions for Astrobiology X, edited by Richard B. Hoover, Gilbert V. Levin, Alexei Y. Rozanov, Paul C. W. Davies, Proceedings of SPIE Vol. 6694 (SPIE, Bellingham, WA, 2007) Article CID Number.

ISSN 0277-786X

ISBN 9780819468420

Published by

SPIE

P.O. Box 10, Bellingham, Washington $98227-0010$ USA

Telephone +1 3606763290 (Pacific Time) · Fax +1 3606471445

SPIE.org

Copyright (c) 2007, Society of Photo-Optical Instrumentation Engineers

Copying of material in this book for internal or personal use, or for the internal or personal use of specific clients, beyond the fair use provisions granted by the U.S. Copyright Law is authorized by SPIE subject to payment of copying fees. The Transactional Reporting Service base fee for this volume is $\$ 18.00$ per article (or portion thereof), which should be paid directly to the Copyright Clearance Center (CCC), 222 Rosewood Drive, Danvers, MA 01923. Payment may also be made electronically through CCC Online at copyright.com. Other copying for republication, resale, advertising or promotion, or any form of systematic or multiple reproduction of any material in this book is prohibited except with permission in writing from the publisher. The CCC fee code is $0277-786 \mathrm{X} / 07 / \$ 18.00$.

Printed in the United States of America.

Publication of record for individual papers is online in the SPIE Digital Library.

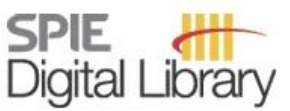

SPIEDigitalLibrary.org

Paper Numbering: Proceedings of SPIE follow an e-First publication model, with papers published first online and then in print and on CD-ROM. Papers are published as they are submitted and meet publication criteria. A unique, consistent, permanent citation identifier (CID) number is assigned to each article at the time of the first publication. Utilization of CIDs allows articles to be fully citable as soon they are published online, and connects the same identifier to all online, print, and electronic versions of the publication. SPIE uses a six-digit CID article numbering system in which:

- The first four digits correspond to the SPIE volume number.

- The last two digits indicate publication order within the volume using a Base 36 numbering system employing both numerals and letters. These two-number sets start with $00,01,02,03,04,05$, 06, 07, 08, 09, OA, OB ... 0Z, followed by 10-1Z, 20-2Z, etc.

The CID number appears on each page of the manuscript. The complete citation is used on the first page, and an abbreviated version on subsequent pages. Numbers in the index correspond to the last two digits of the six-digit CID number. 


\section{Contents}

ix Conference Committee

\section{SESSION 1 THE ORIGIN OF LIFE}

669402 Reduced condition on early Earth and ATP-related mechanism of prebiological evolution (Keynote Paper) [6694-01]

E. M. Galimov, V.I. Vernadsky Institute of Geochemistry and Analytical Chemistry (Russia)

669403 Advanced search for the origin of life's homochirality: asymmetric photon induced processes on chiral compounds with far UV circularly polarized synchrotron radiation (Invited Paper) [6694-02]

L. Nahon, G. Garcia, Synchrotron Soleil (France); I. Powis, Univ. Nottingham (United Kingdom); U. Meierhenrich, Univ. of Nice-Sophia Antipolis (France); A. Brack, Ctr. de Biophysique Moléculaire, CNRS (France)

669404 Could there have been a single origin of life in a big bang universe? [6694-03]

R. Gordon, Univ. of Manitoba (Canada); R. B. Hoover, NASA Marshall Space Flight Ctr. (USA) and National Space Science and Technology Ctr. (USA)

669405 Importance of the interaction between sodium silicate and organic materials to astrobiology: alcohol-based organo-silicates as potential biosignatures [6694-04] P. J. Liesch, V. M. Kolb, Univ. of Wisconsin-Parkside (USA)

669406 Contribution to a symbiogenic approach in astrobiology [6694-05]

F. Carrapiço, L. Pereira, T. Rodrigues, Univ. de Lisboa (Portugal)

\section{SESSION 2 MICROFOSSILS IN ANCIENT ROCKS AND METEORITES}

669408 Microfossils of cyanobacteria in carbonaceous meteorites [6694-07]

R. B. Hoover, NASA Marshall Space Flight Ctr. (USA)

669409 Early Proterozoic (2.04 GA) phosphorites of Pechenga Greenstone Belt and their origin (Invited Paper) [6694-08]

A. Y. Rozanov, M. M. Astafieva, Paleontological Institute (Russia); R. B. Hoover, NASA

Marshall Space Flight Ctr. (USA) and National Space Science and Technology Ctr. (USA)

6694 OA Liquid water in comets: implications for astrobiology [6694-56]

J. T. Wickramasinghe, N. C. Wickramasinghe, W. M. Napier, Cardiff Ctr. for Astrobiology,

Cardiff Univ. (United Kingdom)

\section{SESSION 3 CHEMICAL AND MINERAL BIOMARKERS}

6694 OB Stable sulfur isotopes as probes for ancient life in the solar system (Invited Paper) [6694-10] M. H. Engel, Univ. of Oklahoma (USA) 
6694 OC The case for vestiges of early solar system biota in carbonaceous chondrites: petroleum geochemical snapshots and possible future petroleum prospects on Mars expedition (Invited Paper) [6694-11]

P. K. Mukhopadhyay, Global Geoenergy Research, Ltd. (Canada); D. J. Mossman,

J. M. Ehrman, Mt. Allison Univ. (Canada)

6694 OD Ratios of biogenic elements for distinguishing recent from fossil microorganisms [6694-12] R. B. Hoover, NASA Marshal Space Flight Ctr. (USA) and National Space Science and Technology Ctr. (USA)

\section{SESSION 4 COMETS, METEORITES, AND THE BIOSPHERE}

6694 OG Stardust and comets (Invited Paper) [6694-14]

M. Burchell, Univ. of Kent (United Kingdom)

6694 OH The cometary biosphere (Invited Paper) [6694-15]

R. B. Sheldon, Universities Space Research Association (USA) and National Space Science and Technology Ctr. (USA); R. B. Hoover, NASA Marshall Space Flight Ctr. (USA) and National Space Science and Technology Ctr. (USA)

6694 Ol Dust jets, outbursts, and fragmentation of comets (Invited Paper) [6694-16]

Z. Sekanina, Jet Propulsion Lab. (USA)

\section{SESSION $5 \quad$ LIFE AS WE DO NOT KNOW IT}

6694 OK Searching for an alternative form of life on Earth (Keynote Paper) [6694-19]

P. C. W. Davies, The Beyond Ctr., Arizona State Univ. (USA)

\section{SESSION 6 ASTROBIOLOGY OF VENUS, MARS, AND ICY MOONS}

6694 OL Titan: an astrobiological laboratory in the solar system (Keynote Paper) [6694-20]

F. Raulin, M.-J. Nguyen, P. Coll, LISA, CNRS, Univ. Paris 7 and Univ. Paris 12 (France)

6694 0M The revival of life on Mars (Invited Paper) [6694-21]

G. V. Levin, Spherix, Inc. (USA)

$6694 \mathrm{ON}$ The hydrogen peroxide-water hypothesis for life on Mars and the problem of detection [6694-22]

J. M. Houtkooper, Justus-Liebig Univ. of Giessen (Germany); D. Schulze-Makuch,

Washington State Univ. (USA) 
669400 The Biological Oxidant and Life Detection (BOLD) mission: an outline for a new mission to Mars [6694-23]

D. Schulze-Makuch, Washington State Univ. (USA); J. M. Houtkooper, Justus-Liebig Univ. of Giessen (Germany); M. Knoblauch, Washington State Univ. (USA); R. Furfaro, Univ. of Arizona (USA); W. Fink, California Institute of Technology (USA); A. G. Fairén, NASA Ames Research Ctr. (USA); H. Vali, McGill Univ. (USA); J. N. Head, Raytheon Missile Systems (USA); D. S. S. Lim, NASA Ames Research Ctr. (USA); J. Dohm, Univ. of Arizona (USA); L. N. Irwin, Univ. of Texas at El Paso (USA); M. Daly, MDA, Ltd. (USA); D. Andersen, Carl Sagan Ctr. for the Study of Life in the Universe (USA)

6694 OP The Phoenix mission to Mars (Invited Paper) [6694-24]

P. H. Smith, The Lunar and Planetary Lab., Univ. of Arizona (USA)

\section{SESSION 7 DISTRIBUTION OF LIFE}

6694 OS Diatoms: unique eukaryotic extremophiles providing insights into planetary change (Invited Paper) [6694-27]

J. P. Kociolek, California Academy of Sciences (USA) and Univ. of Michigan Biological Station (USA)

6694 OT How do bacteria reach the stratosphere? [6694-29]

M. Wainwright, Univ. of Sheffield (United Kingdom)

6694 OU VUV-UV absorption spectroscopy of DNA and UV screens suggests strategies for UV resistance during evolution and space travel (Invited Paper) [6694-30]

A. Zalar, D. Tepfer, Institut National de la Recherche Agronomique (France);

S. V. Hoffmann, Univ. of Aarhus (Denmark); A. Kollmann, Institut National de la Recherche Agronomique (France); S. Leach, Observatoire de Paris-Meudon (France)

$66940 \mathrm{~V}$ Diatoms in space: testing prospects for reliable diatom nanotechnology in microgravity [6694-31]

R. Gordon, Univ. of Manitoba (Canada); R. B. Hoover, NASA (USA); J. A. Tuszynski, Univ. of Alberta (Canada); J. de Luis, Payload Systems, Inc. (USA); P. J. Camp, Univ. of Edinburgh (United Kingdom); M. A. Tiffany, San Diego State Univ. (USA); S. S. Nagy, Montana Diatoms (USA); M. Fayek, University of Manitoba (Canada); P. J. Lopez, Ecole Normale Supérieure (France); B. E. Lerner, Univ. of Manitoba (Canada)

\section{SESSION 8 MICROBIAL EXTEMOPHILES}

6694 OW Extremophiles and chemotrophs as contributors to astrobiological signatures on Europa: a review of biomarkers of sulfate-reducers and other microorganisms (Invited Paper) [6694-32]

J. Seckbach, The Hebrew Univ. of Jerusalem (Israel); J. Chela-Flores, The Abdus Salam International Ctr. for Theoretical Physics (Italy) and Instituto de Estudios Avanzados (Venezuela)

6694 0X Characterization of a moderately halo-acidophilic bacterium isolated from Lake Brown, western Australia [6694-33]

M. R. Mormile, B. Hong, N. T. Adams, Univ. of Missouri-Rolla (USA); K. C. Benison, Central Michigan Univ. (USA); F. Oboh-lkuenobe, Univ. of Missouri-Rolla (USA) 
6694 OY Diversity, evolution, and horizontal gene transfer (HGT) in soda lakes [6694-34]

H. C. Pinkart, Central Washington Univ. (USA); M. C. Storrie-Lombardi, Kinohi Institute (USA)

$66940 Z$ Investigating microbial diversity and UV radiation impact at the high-altitude Lake Aguas Calientes, Chile [6694-35]

L. Escudero, G. Chong, Ctr. de Investigación Científica y Tecnológica para la Minería (Chile); C. Demergasso, Univ. Católica del Norte (Chile); M. E. Farías, Consejo Nacional de Investigaciones Científicas y Técnicas (Spain); N. A. Cabrol, E. Grin, NASA Ames Research Ctr. (USA) and CSC, SETI Institute (USA); E. Minkley, Jr., Y. YU, Carnegie Mellon Univ. (USA)

669410 Mitigation of environmental extremes as a possible indicator of extended habitat sustainability for lakes on early Mars (Invited Paper) [6694-36]

N. A. Cabrol, E. A. Grin, NASA Ames Research Ctr. (USA) and CSC, SETI Institute (USA);

A. N. Hock, Univ. of California, Los Angeles (USA)

\section{SESSION 9 INSTRUMENTS AND METHODS FOR ASTROBIOLOGY}

669411 A nanopore-ARROW biosensor for life detection [6694-37]

D. Deamer, H. Schmidt, Univ. of California, Santa Cruz (USA); A. R. Hawkins, Brigham Young Univ. (USA)

669412 MR PRISM: a software suite for CRISM analysis [6694-40]

A. J. Brown, SETI Institute (USA); M. Storrie-Lombardi, Kinohi Institute (USA)

669413 High-resolution light microscopy of nanoforms [6694-41]

V. Vodyanoy, O. Pustovyy, A. Vainrub, Auburn Univ. (USA)

669414 In situ search for life traces in extraterrestrial samples by synchrotron x-ray fluorescence 2D and 3D imaging [6694-42]

L. Lemelle, ENS Lyon, Univ. de Lyon (France); A. Simionovici, Observatoire des Sciences de I'Univers de Grenoble (France); M. Salomé, P. Blevet, J. Susini, European Synchrotron

Radiation Facility (France); P. Gillet, ENS Lyon, Univ. de Lyon (France)

\section{SESSION 10 SURVIVABILITY TO RADIATION, DESSICATION, AND SHOCK}

669415 Great Salt Lake halophilic microorganisms as models for astrobiology: evidence for desiccation tolerance and ultraviolet irradiation resistance [6694-43]

B. K. Baxter, B. Eddington, M. R. Riddle, T. N. Webster, B. J. Avery, Westminster College (USA)

669416 Survival of microbial life under shock compression: implications for Panspermia [6694-44] M. Burchell, Univ. of Kent (United Kingdom)

669417 ATCG nucleotide fluctuation of Deinococcus radiodurans radiation genes [6694-45] T. Holden, R. Subramaniam, R. Sullivan, E. Cheung, C. Schneider, G. Tremberger, Jr., A. Flamholz, D. H. Lieberman, T. D. Cheung, CUNY Queensborough Community College (USA)

669418 Radiotolerance of microorganisms isolated from radiation fields on a university campus: implications for shallow subsurface growth of microorganisms on Mars [6694-46]

M. R. Mormile, J. J. Elmer, S. J. Spychala, Univ. of Missouri-Rolla (USA) 
669419 Astrobiological polarimeter [6694-47]

N. Kothari, A. Jafarpour, T. L. Thaler, R. Trebino, A. S. Bommarius, Georgia Institute of Technology (USA)

6694 1A Apparent biotic micromorphologies of abiotic origin [6694-50]

G. Konesky, SGK Nanostructures, Inc. (USA)

6694 1B Is there red soil on Mars? (as proof of water and vegetation) [6694-51]

R. Paepe, Geobound International, BV MUHS (Netherlands)

6694 1C Microbial extremophiles in evolutionary aspect [6694-52]

E. V. Pikuta, R. B. Hoover, NASA Marshall Space Flight Ctr. (USA) and National Space

Science and Technology Ctr. (USA)

6694 1D Remote sensing capacity of Raman spectroscopy in identification of mineral and organic constituents [6694-53]

B. Chen, C. Stoker, N. Cabrol, C. P. McKay, NASA Ames Research Ctr. (USA)

6694 1E Co-evolution of cyanophage and cyanobacteria in Antarctic lakes: adaptive responses to high UV flux and global warming [6694-54]

M. C. Storrie-Lombardi, Kinohi Institute (USA); H. C. Pinkart, Central Washington Univ. (USA)

POSTER SESSION

$6694 \mathrm{IF} \quad$ Living strategies of unusual life forms on Earth and the relevance to astrobiology (Invited Paper) [6694-48]

P. J. Liesch, V. M. Kolb, Univ. of Wisconsin-Parkside (USA)

6694 1G The importance of the Maillard-metal complexes and their silicates in astrobiology [6694-49]

P. J. Liesch, V. M. Kolb, Univ. of Wisconsin-Parkside (USA)

\section{ADDITIONAL PAPER}

$6694 \mathrm{1H} \quad$ Large multicellular filamentous bacteria under the oxygen minimum zone of the eastern South Pacific: a forgotten biosphere [6694-57]

V. A. Gallardo, C. Espinoza, Univ. de Concepción (Chile)

Author Index 
Downloaded From: https://www.spiedigitallibrary.org/conference-proceedings-of-spie on 25 Apr 2023

Terms of Use: https://www.spiedigitallibrary.org/terms-of-use 


\title{
Conference Committee
}

\author{
Conference Chairs
}

Richard B. Hoover, NASA Marshall Space Flight Center (USA) and National Space Science and Technology Center (USA)

Gilbert V. Levin, Spherix, Inc. (USA)

Alexei Y. Rozanov, Paleontological Institute (Russia)

Paul C. W. Davies, The Beyond Center, Arizona State University (USA)

Program Committee

Mian M. Abbas, NASA Marshall Space Flight Center (USA)

Sabit S. Abyzov, Institute of Microbiology (Russia)

Marina M. Astafieva, Paleontological Institute (Russia)

Stanley M. Awramik, University of California, Santa Barbara (USA)

Bonnie K. Baxter, Westminster College (USA)

Lee Bebout, NASA Ames Research Center (USA)

Kathleen C. Benison, Central Michigan University (USA)

Adrian J. Brown, SETI Institute (USA)

Donald E. Brownlee, University of Washington (USA)

Mark A. Bullock, Southwest Research Institute (USA)

Mark J. Burchell, University of Kent (United Kingdom)

Nathalie A. Cabrol, NASA Ames Research Center (USA) and CSC, SETI Institute (USA)

Francisco J. Carrapiço, Universidade de Lisboa (Portugal)

Bin Chen, NASA Ames Research Center (USA)

Max L. Coleman, Jet Propulsion Laboratory (USA)

David W. Deamer, University of California, Santa Cruz (USA)

Michael H. Engel, University of Oklahoma (USA)

Sabrina Feldman, Jet Propulsion Laboratory (USA)

Eric M. Galimov, V.I. Verdansky Institute of Geochemistry and

Analytical Chemistry (Russia)

David H. Grinspoon, Denver Museum of Art and Science (USA)

J. Patrick Kociolek, California Academy of Sciences (USA) and University of Michigan (USA)

Vera M. Kolb, University of Wisconsin-Parkside (USA)

Jere H. Lipps, University of California, Berkeley (USA)

Gene D. McDonald, The University of Texas at Austin (USA)

David S. McKay, NASA Johnson Space Center (USA)

Uwe Meierhenrich, Université de Nice Sophia Antipolis (France)

Melanie R. Mormile, University of Missouri-Rolla (USA)

David J. Mossman, Mount Allison University (Canada)

Roland R. Paepe, Geobound International, BV MUHS (Netherlands) 
Randall S. Perry, Imperial College London (United Kingdom)

Elena V. Pikuta, NASA Marshall Space Flight Center (USA) and National Space Science and Technology Center (USA)

Holly C. Pinkart, Central Washington University (USA)

Malcom Potts, Virginia Polytechnic Institute and State University (USA)

Lisa M. Pratt, Indiana University (USA)

Francois C. Raulin, LISA, CNRS, Université Paris 7 and Université Paris 12 (France)

Birgit I. Sattler, Leopold-Franzens-University Innsbruck (Austria)

Joseph Seckbach, The Hebrew University of Jerusalem (Israel)

Zdenek Sekanina, Jet Propulsion Laboratory (USA)

Mark A. Sephton, Imperial College London (United Kingdom)

Alexandre S. Simionovici, Observatoire des Sciences de l'Univers de Grenoble (France)

Paul P. Sipiera, Harper College (USA)

Peter H. Smith, The Lunar and Planetary Laboratory, University of Arizona (USA)

Michael C. Storrie-Lombardi, Kinohi Institute (USA)

Vitaly J. Vodyanoy, Auburn University (USA)

Milton Wainwright, University of Sheffield (United Kingdom)

Max K. Wallis, Cardiff University (United Kingdom)

Nalin C. Wickramasinghe, Cardiff Center for Astrobiology, Cardiff University (United Kingdom)

Andreja Zalar, Institut National de la Recherche Agronomique (France)

Georgi A. Zavarzin, Institute of Microbiology (Russia)

Session Chairs

1 The Origin of Life

David S. McKay, NASA Johnson Space Center (USA)

David W. Deamer, University of California, Santa Cruz (USA)

2 Microfossils in Ancient Rocks and Meteorites

Eric M. Galimov, V.I. Vernadsky Institute of Geochemistry and Analytical Chemistry (Russia)

Vera M. Kolb, University of Wisconsin-Parkside (USA)

3 Chemical and Mineral Biomarkers

Mark J. Burchell, University of Kent at Canterbury (United Kingdom)

Zdenek Sekanina, Jet Propulsion Laboratory (USA)

4 Comets, Meteorites, and the Biosphere

Gilbert V. Levin, Spherix, Inc. (USA)

Max L. Coleman, Jet Propulsion Laboratory (USA) 
Life as We Do Not Know It

Richard B. Hoover, NASA Marshall Space Flight Center (USA) and National Space Science and Technology Center (USA)

6 Astrobiology of Venus, Mars, and Icy Moons

Peter H. Smith, The Lunar and Planetary Laboratory, University of Arizona (USA)

$7 \quad$ Distribution of Life

Francois C. Raulin, LISA, CNRS, Université Paris 7 and Université Paris 12 (France)

Melanie R. Mormile, University of Missouri-Rolla (USA)

8 Microbial Extemophiles

Mark A. Bullock, Southwest Research Institute (USA)

J. Patrick Kociolek, California Academy of Sciences (USA) and University of Michigan (USA)

9 Instruments and Methods for Astrobiology

Richard B. Hoover, NASA Marshall Space Flight Center (USA) and National Space Science and Technology Center (USA)

Michael C. Storrie-Lombardi, Kinohi Institute (USA)

10 Survivability to Radiation, Dessication, and Shock

Nathalie A. Cabrol, NASA Ames Research Center (USA) and CSC, SETI Institute (USA)

Lee Bebout, NASA Ames Research Center (USA)

11 Chirality and Astrobiology

Joseph Seckbach, The Hebrew University of Jerusalem (Israel)

Milton Wainwright, University of Sheffield (United Kingdom) 
Downloaded From: https://www.spiedigitallibrary.org/conference-proceedings-of-spie on 25 Apr 2023

Terms of Use: https://www.spiedigitallibrary.org/terms-of-use 